\title{
Ammattikasvatus elinikäisen oppimisen ympäristössä
}

\author{
Harney, K., Heikkinen, \\ A., Rahn, S., \& Schem- \\ mann, M. (ed. 2002). \\ Lifelong Learning: One \\ Focus, Different Sys- \\ tems. Studien zur Er- \\ wachsenenbildung, \\ Band 19. Frankfurt am \\ leen olevan voimaa tuoda yh- \\ teen kirjoittaja ja kustantaja. \\ Siihen liittyy myös piirteitä, \\ jotka luonnehtivat pyhää tai \\ pyhäksi pyrkivää (yksi fo- \\ kus!). Onkin ilmeistä, että \\ elinikäisen oppimisen ideassa \\ muhii myös kasvava provoka- \\ tiivinen voima.
} Main: PETER LANG

\section{Elinikäisen oppimisen} ideaalista on vielä tuomaan yhteen tutkijat, työelämän edustajat sekä hallinto. Tulevat, yhä suuremman osan elinajastaan opiskelevat oppijat, joihin sisältyy merkittävä koulutusuraansa loputta polkevien kansalaisten joukko, loistavat poissaolollaan. Kun tulevaisuuden luonnostelijat uskovat olevansa hyvällä asialla ja asiantuntijoina ponnistelemassa paremman maailman puolesta, niin viis kansalaisista - hyväähän tässä ollaan kaikille tarkoittamassa ja välttämättömään varautumassa. Ehkäpä ainoa tapa varmistaa se, ettei joudu taas kouluttautumaan uuteen ammattiin, on puhua ammatikseen siitä, miten tulevaisuudessa joudutaan kouluttautumaan uudelleen ja uudelleen.

Ideaalilla on voimaa myös myös diskurssina. Se artikuloituukin sujuvasti niin riviopiskelijoiden kuin johtavien poliitikkojenkin puheissa ja kääntyy oikeuttamaan näin pyrkimyksiä, joiden oikeuttamiseen ennen käytettiin toisia sanoja, toisia ideoita, toisia diskursseja.

Elinikäinen oppiminen -nimikkeellä näyttäisi edel-
Klaus Harney ym. toimittaman teoksen otsikko - yksi fokus, erilaisia systeemejä rakentaa siltaa taivaallisen ja maallisen välille. Utopismi ja kun kohti parempaa, mahdollisesti myös aikaisempaa jaetumpaa maailmaa ponnistellaan eri puolilla, erilaisista lähtökohdista ja vaihtelevista konteksteista käsin. Tätä kansallisten, alueellisten ja kulttuuristen lähtökohtien erilaisuutta korostetaan useammassakin teoksen artikkeleista. Artikkeleita on johdanto mukaan luettuna kaikkiaan 18. Taustalta löytyy 20 kirjoittajaa, joista valtaosa tulee Saksasta, erityisesti Bochumin yliopistosta, muutama Norjasta, pari Suomesta sekä edustajat Englannista ja Ruotsista.

Tuotoksesta vastaa aktiivinen ja aikaansaava tutkijaverkosto, joka perkaa ammattikasvatusta, sen historiaa, käytäntöjä ja ongelmia.

\section{Tulevaisuuteen}

yhdistettävien utopioiden haasteena on selviytyä hyvää tarkoittavista todentamispyrkimyksistä. Utopiat kestävät harvoin vertailua käytäntöihin, joiden sanotaan niitä ilmentävän, tai politiikkoihin, joilla niitä väitetään edistettärealismi lyövät kättä yhteen, vän. Yleensä osoittautuu, että maailmalla on enemmän voimaa muuttaa utopioita kuin utopioilla maailmaa.

\section{Toimittajat tuovat}

johdannossa esiin elinikäisen oppimisen termin kyvyn sulkea (sulattaa) piiriinsä moninaisia ilmiöitä, edistää kansainvälistä yhteistyötä ja kanssakäymistä. Madhu Singh, Michael Schemmann, Katrin Kraus, Philipp Gonon sekä Antony Lindgren tarkastelevatkin artikkeleissaan elinikäistä oppimista poliittisena ideana.

\section{Aikuisten oikeus oppimi-} seen on Singhin mukaan demokratisoinut koulutusta. Oikeus oppimiseen voi toteutua vain yhteiskunnassa, joka kykenee takaamaan myös monien muiden perusoikeuksien toteutumisen ja jossa eri instituutioiden (työ, perhe, yhdistykset jne.) kasvatuspotentiaali tulee löydetyksi. Monoliittisia ratkaisuja ei kuitenkaan ole odotettavissa eriytyneessä maailmassa. Elinikäisestä oppimisesta vallitsee monia versioita - vastaavastiko kuten esimerkiksi demokratiasta, yhdenvertaisuudesta tai rauhasta, voisi skeptikko kysyä.

\section{Schemmann tavoittelee} selitystä elinikäisen oppimisen idea synnylle 60-70 -luvuilla (UNESCO), keskustelun taantumiselle (taantuma, kulttuurinen eriytyminen, epäluulo universaaleja malleja kohtaan) ja sen uudelle tulemiselle (modernisaatio, globalisaatio). Selitykset ovat 
ohuita. Hänen mielestään aikuiskasvatustieteilijöillä on ohittamatonta asiantuntemusta käsitteen kehitelyssä. Ei kuitenkaan ole kirkossa kuulutettua, että heiltä löytyisi vaikeasti ohitettavia argumentteja, kun areenana on julkinen keskustelu, eikä esimerkiksi komiteatyö. Kraus raportoi ohjelmatekstejä koskevia havaintojaan, mutta kiinnostava kirjoitelma jää jostakin syystä kokolailla torsoksi. Myös Gononin kiinnostusta herättävä "käsite vai slogan" -tarkastelu typistyy aikuisopetuksen lyhyeksi historiaksi ikään kuin elinikäisen oppimisen käytännön historiana. Lindgren tarkastelee elinikäistä oppimista suhteessa ammattikoulutuksen kehkeytymiseen Ruotsissa, työelämän uusiin järjestelyihin, joiden myötä kompetenssien osalta palataan 1900-luvun alkuun, sekä talouteen, politiikkaan ja ideologiaan. Suhteutettava elinikäinen oppiminen haihtuu tarkastelun kuluessa näkymättömiin.

\section{Katja Brause ja Christine} Meyer kiinnittävät huomiota elinikäisen oppimisen idean sukupuoliulottuvuuteen ja valottavat artikkelissaan sukupuolten välisen tasa-arvon kehitystä Saksassa. Äitiys vähentää osallistumismahdollisuuksia, mutta isäksi tuleminen edesauttaa jatkokoulutukseen hakeutumista. Osallistumismahdollisuudet eivät jakaudu tasaisesti yli ammattien, toimialojen ja työsuhdetyyppien. Naisten työt jakaa nyt useampi osa-aikaisesti työskentelevä nainen kuin ennen. Siinä missä miehille on tarjolla lähinnä yksi työmarkkinaorientaation malli, voivat naiset varioida omaa orientaatio- taan. Kun elinikäisen oppimisen strategiat istuvat paremmin miesten orientaatioon, eivät ne todennäköisesti ainakaan korjaa naisten asemaa suhteessa työhön. Mahdollisesti tapahtuu päinvastoin.

\section{Anja Heikkinen ja Lea}

Henriksson luonnehtivat työelämän muutosta terveyden ja tekniikan aloilla Suomessa.

Artikkeli on kokoelman pisin ja teksti lastattu ajatuksilla, havainnoilla, aspekteilla ja ulottuvuuksilla. Siinä ilmentävät itsessään monet niistä asioista, joista se puhuu: hektisyys, intensiteetti, kokonaiskuvan hajoaminen, merkityksen pilkkoutuminen ja massaan häviäminen. Lukijaltakin vaaditaan huomattavaa työpanosta. Klaus Harney puolestaan tarkastelee ristivetoisuuksia, joita sisältyy työssä tapahtuvassa koulutuksessa.

\section{Thomas Deissinger}

vertailee ammattiin koulutusta Englannissa ja Saksassa. Hänen mielestään molemmat maat voivat oppia toinen toisiltaan, Englanti ammatillisen peruskoulutuksen ja Saksa jatkokoulutuksen järjestämisessä, ja kehittyä näin järjestelmiltään yhteismitallisemmiksi. Kokoelman ehkä kiinnostavimmassa artikkelissa Sylvia Rahn kritisoi näkemystä, että ammatti-instituution kohtalona olisi Saksassa korvautua elinikäisen oppimisen yksilöllisellä instituutiolla. Taustoitusta tähän teemaan tarjoaa Ole Johnny Olsenin kirjoitus, jossa hän kuvaa tutustumistaan Saksassa ammateista ja ammattikasvatuksesta käytyyn keskusteluun sekä taustalta löytyvään disipliiniin. Rudolf Huseman puolestaan etenee toiseen suuntaan kuin Sylvia
Rahn ja pohtii omaehtoisen, elämänkokemusten reflektoinnista kehkeytyvän aikakäsitteen asemaa ja tuottamista elinikäisen itseorganisoidun oppimisen edellytyksenä. Kokonaisuuden antia laajentavat edelleen tekstit Keski-Englannin tilasteesta (Stephen Drodge), ammattiliiton näkemyksestä (Bernd Kassebaum), analyysi työnantajien ja työntekijöiden sekä sosiaalisen ja inhimillisen pääoman suhteesta elinikäisen oppimiseen (Marcus Reinecke) sekä Norjan ammattikoulutuksen järjestelmästä (Sven Michelson \& Håkon Host).

\section{Kokonaisuus on}

väistämättä tilkkutyötä. Ajatuksen kehittely jää useassa artikkelissa puolitiehen, ellei sitten kokonaan lähtökuoppiinsa. Teos sisältääkin runsaasti tekemätöntä toimitustyötä huolimatta siitä, että toimittajia löytyy, ainakin nimellisesti, peräti neljä. Konferenssijulkaisuna kokoelma kuitenkin dokumentoi ammattikasvatuksen kansainvälisen tutkijaverkoston yhden kehitysvaiheen. Kirjan otsikko onkin parempi ymmärtää väljäksi teemaksi ko. kokoontumiselle kuin ideaksi, jota tämän kokoelman teksteissä kässiteltäisiin syvällisesti, monipuolisesti ja systemaattisesti. Teos antaa kuitenkin kuvan siitä, miten paljon tutkimusja keskusteluperinne ammattikasvatuksessa sekä alan akateeminen etabloituminen Saksassa eroavat esimerkiksi tilanteesta Suomessa ja Norjassa. Ehkäpä Euroopan yhdentyminen jatkossa tasoittaa suhteellisia eroa tässäkin suhteessa.

VesaHuotari 